\title{
Befriending the Darkness: L.M. Montgomery's Lived Theodicy in Anne's House of Dreams
}

Published on

Mon, 10/25/2021 - 09:17

In Anne's House of Dreams, which Elizabeth Epperly calls Montgomery's most philosophical novel, Montgomery delves into painful topics of loss, suicide, bad marriages, ill-timed love, poverty, and the beautiful-terrible consequences of duty. The result is a complex and nuanced consideration of faithful living in the face of unexplainable evil that functions as a lived theodicy in story form.

"I reckon when the darkness is close to us it is a friend. But when we sorter push it away from us-divorce ourselves from it, so to speak, with lantern light-it becomes an enemy."

-L.M. Montgomery, Captain Jim in Anne's House of Dreams

On Thursday, 5 October 1916, L.M. Montgomery completed her fourth Anne novel, Anne's House of Dreams. As she admits in her diary, her writing experience was mixed: "I never wrote a book in so short a time and amid so much strain of mind and body. Yet I rather enjoyed writing it and I think it isn't too bad a piece of work. I am glad it is done however. It has taken a lot out of me." 1 The strain was genuine for Montgomery. Critics agree that contemporaneous personal and professional struggles find their way into Montgomery's work of the period, specifically the Four Winds trilogy-Anne's House of Dreams, Rainbow Valley, and Rilla of Ingleside -which Montgomery writes "against the ravages of war."2 In 1908, Montgomery set down something of a vision statement for her writing: "Thank God, I can keep the shadows of my life out of my work. I would not wish to darken any other life-I want 
instead to be a messenger of optimism and sunshine." $\underline{3}$ Yet, a prevailing darkness that sits in contrast to the overarching light is especially prevalent in Anne's House of Dreams-what William V. Thompson calls a "shadow" on the tale, and Owen Dudley Edwards and Jennifer H. Litster describe as the "death of innocence." $\underline{4}$

Elizabeth Epperly's analysis of Anne's House of Dreams in The Fragrance of SweetGrass highlights the critical ways that Montgomery brings together comedy and tragedy, life and death, friendship and struggles, love and loss, in a single, deeply personal novel. "Everything in this novel is made to harmonize," Epperly argues, so that the general sweep of the novel's action is toward change ultimately designed for the good. The "Four Winds harmony," as Epperly describes it, gives images of strength and a path to endurance. $\underline{5}$ The metaphor of harmony is particularly apt given the various tensions and struggles that Montgomery introduces in the novel. However, in a novel of contrasts, do all things truly harmonize? The question shows the value of problematizing Epperly's rich metaphor of "harmony." A chord is not composed of a single note. Harmony allows for complementarity, contrast, and the blending of features that still honours the distinctive voices that come together in song. In considering the darkness and shadows and the metaphor of "contrast," we need to ask whether anything dissonant remains in the novel. Ultimately, can one harmonize darkness and light?

Because Epperly's analysis of the novel brings such rich results, there is value in troubling her metaphor of harmony. Using Heather Walton's terms for theological approaches to literary study, I will "interrogate" the metaphor of harmony in order to "generate" a new understanding of the text's meanings. 6 In particular, by looking more deeply at the contrasts in Anne's House of Dreams and asking to what degree they harmonize and to what degree distinctive or even dissonant notes seem to remain, I argue that an intuitive and skillful philosophical message emerges from Montgomery's poetic prose.

In a providential universe, the beauty and love and friendship in Anne's House of Dreams sit in theological tension with the great losses and sorrows that fill the novel. The story invites the question of why such suffering is permitted-"the origin of evil," as Captain Jim voices the question. $\underline{7}$ In philosophical and theological terms, "the problem of evil refers to the logical tension between belief in divine goodness and omnipotence on the one hand and the ubiquitous reality of suffering on the other, especially unjust or innocent suffering."요 Although he has a much different rhetorical accent, Captain Jim anticipates the twenty-first-century Christian 
philosopher Alvin Plantinga, who summarizes the questions this way: "Why does God permit evil, or why does he permit so much of it, or why does he permit those horrifying varieties of it?" 9 The attempt to answer these questions is what philosophers call a "theodicy." Canadian philosopher of religion Mark Scott describes the term in this way: "The technical term theodicy signifies the defense of divine justice in the face of evil. It employs logical strategies to 'justify the ways of God to men,' that is, to vindicate God from moral culpability. More broadly, theodicy denotes the attempt to explain or make sense of suffering." Scott quotes John Milton from his prologue to the great English poem Paradise Lost, for theodicy-making is not just the task of professional theologians and philosophers but also of pastors, priests, neighbours, and friends-including novelists and poets. Particular to my paper, Scott argues that theodicy-making is a storytelling venture, for "[t]heodicy tells a 'story' about how God and evil logically coexist." $\underline{10}$

Montgomery was a consummate storyteller with a lithe mind. Writing in a period of her own indescribable suffering, she instinctively engages in a project of narrative theodicy-making in Anne's House of Dreams that shows remarkable philosophical sophistication. Characters question the justice, fairness, and goodness of God with an intensity of theological pressure rare in Montgomery's books. These questions are particularly striking as so much of the discussion is overtly religious, including jokes, barbs and debates, 11 ethical choices, struggles with meaning and vocation, and poignant moments of reflection. Without dismissing the dark aspects of life-indeed, illuminating the darkness, as Epperly puts it12-but without answering every question and doubt, Montgomery is able to offer a lived theodicy in fiction that is practically oriented and spiritually inviting. "To encounter even a slight fraction of the breadth and depth of evil in the world," Scott argues, "outstrips our intellectual, emotional, and spiritual capacities, and leaves us winded and wounded. Theodicy traverses the shadowlands of suffering, where dangers await at every step and darkness shrouds the long, tortuous road ahead."13 "Traversing the shadowlands of suffering" is a good description of Anne's House of Dreams, in which Montgomery provides a practical response to the problem of evil through an exploration of themes of darkness and light. This search for an answer, what the narrator calls "the riddle of the universe," 14 is organic both to the message of love and hope and the strains of shadow that critics have noted in the novel.

Specifically, by making friends with the darkness, as Anne and Captain Jim propose, and by allowing all the contrasting hues of light and shadow to live in the book, 
Montgomery can credibly retain trust in Providence while shifting the foundation of "the problem of evil" to "the question of what I will choose to do"-that is, the question of duty based on what is right. In shifting from philosophical questioning to moral action without negating the problematic questions, Montgomery skillfully uses narrative and imagery to create a soul-shaping theodicy in story form for readers who would not be trained in the philosophical complexities of the problem. As a result, she invites a practical, ethical, spiritual response rather than a formal metaphysical structure-what Scott calls "[r]edefining theodicy in experiential, practical directions"-in a way that does not negate the utility or urgency of what Captain Jim calls the "onunderstandable" and pressing questions of lived experience.15 Indeed, writing this novel while experiencing the pains of loss and war is itself Montgomery's spiritual theological response in the face of incomprehensible suffering-an act of theodicy-making that models her narrative lived theodicy.

\section{Strains of Mind and Body: The Context of Writing Anne's House of Dreams}

By the autumn of 1913, Montgomery had published her sixth novel, with continuing strong sales following the staggering success of Anne of Green Gables. Newly married to a Presbyterian minister, Montgomery had established her own home in Leaskdale, Ontario. In the following year, she gave birth to a son-an experience of motherhood that was like "a revelation from God." 16 Two of Montgomery's dreams very much in doubt a few years before-literary success and motherhood-had come true. Only one year later, Montgomery's second child, Hugh Alexander, was dead in her arms just as she received news from Europe about the world's first great global technological war. "Everything seems dark and hopeless," Montgomery wrote in her journal.17 This terrible season of war and loss began a five-year period of heightened anxiety for her, with obsessive news-watching, a series of lawsuits, the death of her dearest friend, the loss of many local young men to war, and the emergence of her husband's melancholia and consequent anxiety, seasonal depression, and sleeplessness.18 "This war is slowly killing me," Montgomery confided to her journal in 1916.19 As she was "stretched between her duties as a minister's wife, a mother, and a writer, and her worries about the war," biographer Mary Rubio notes that Montgomery's physical health was in some degree of peril. 20

Even amid the personal turmoil, grief, and exhaustion of this period, Montgomery experienced moments of joy, including the birth of her youngest son, Stuart, in 1915. Despite a literary legal battle that would not be resolved until 1928, the 
constant demands of motherhood, and increased responsibilities in support of the war effort, Montgomery was productive as a writer. By the end of the decade, Montgomery would complete four more Anne novels, a collection of poetry, and the literary memoir that would become The Alpine Path. One of these novels is Anne's House of Dreams, written in the months after the loss of infant Hugh Alexander and the outbreak of war, beginning a new cycle of stories with Anne as the adult, maternal, domestic figure.

\section{Light and Shadow in Anne's House of Dreams}

Anne's House of Dreams contains hundreds of references to light, including lamps, mirrors, fireplaces, stars and suns, sunsets and sunrises, various degrees of twilight, and shining eyes, faces, and spirits. Likewise, there are hundreds of references to darkness and shadow. So many of the novel's crucial moments happen at nighttime, and the liminal spaces at dusk and dawn are the heart-rending and hopeful moments of life and death. Mary Rubio and Elizabeth Waterston aptly observe that, despite the realism of her novels, Montgomery's "experience and awareness of darknesses and depths, both in society and in private experience, are given scant place in her fiction" and that the journals give a "more complete picture of her background, her time, and her society." 21 In the case of Anne's House of Dreams, however, I argue that in the contrasts of light and darkness, Montgomery captures both societal and personal depths akin to what Rubio and Waterston discern in the journals. Rubio and Waterston's description of the dynamic nature of Montgomery's journal-writing applies to Anne's House of Dreams as well: in this novel, Montgomery bridges "the iron necessities" of life's struggle with "the golden world she created for her readers." 22

Scholars have noted the value of these contrasts in the novel. Gillian Thomas argues that Anne's House of Dreams touches on "much darker themes," agreeing with Alana Vincent's description of a "dark realism" alien to her pre-war novels. 23 In Ashley Cowger's terms, Anne's House of Dreams is "bursting with images of suicide, death, and depression." 24 Though Anne's House of Dreams includes numerous happy endings, the novel concludes with the death of a dear friend and the need for Anne and Gilbert to leave their House of Dreams. From the devastating loss of Anne's first child, little Joy, to the multi-act horror that is Leslie's tragedy, the first novel Montgomery wrote entirely during the First World War evinces a bracing quality of sorrow and loss. Certainly, as Rubio notes, Anne's House of Dreams 
"introduces events and emotions more troubling than ever before." $\underline{25}$

All the evidence suggests that Montgomery not only fails to keep darknesses out of Anne's House of Dreams but provides, in Thompson's words, a "darkening" world, a "shadow" on the House of Dreams that results in "a change in the fictional life of Anne." Thompson concentrates upon the way the novels of this period "represent the intersection of Montgomery's public and private lives." 26 Epperly takes this further, demonstrating that in this "tightly woven, wise story," Montgomery is offering like-minded war-beleaguered readers, who revere "the beauty of the world and the drama of its rhythms and traditions," a belief in home and trust even when "[c]hange and evil threaten." With these motifs of darkness and shadows and Montgomery's encouragement in the face of tribulation, Epperly's analysis of Anne's House of Dreams attends closely to images of light and colour: "Throughout the novel light plays an important part, and Montgomery ties the images together with the lighthouse (and, by both metaphor and metonymy, with Captain Jim); she uses the light itself, the lighthouse 'star,' stars, and firelight to suggest the various symbolic interpretations of illumination in darkness." 27 The lighthouse and friendly hearths, the shadow of Venus and starlit nights, dawn and dusk, spring sunshine and pale winter light, splashes of gold and red, the "effects of light and shadow all along these shores"-all of these images come together in the novel "to suggest how all things illumine and modify each other if love (or the loving eye) is present." $\underline{28}$

Epperly's reading of Anne's House of Dreams is an integrative and integrating one, using the metaphor of "harmony" to describe Montgomery's work in the novel: "Everything in this novel is made to harmonize; all things, it is suggested, change in unexpected and (if we are patient and faithful) often delightful ways." Epperly argues that Anne's House of Dreams is "the most consciously poetic of Montgomery's novels," while at the same time being "the most unselfconsciously philosophic." Thus, for Epperly, "Montgomery uses colour and symbol in this novel to enrich our understanding of spiritual affinity and love of beauty"-imaged in the novel in the "twinned" relationship of Anne and Leslie (discussed in the next section of my paper), and in the sea as a visual focal point of contrasts. For Epperly, the sea in Anne's House of Dreams represents Montgomery's harmonization of diverse themes: "Abiding, yet ever-changeful, at times serene and at times savage, the sea suggests the quality of Four Winds life. The apparent power, beauty, mystery, melancholy, caprice, and joy of the harbour and gulf reflect as well as affect the moods and personalities of the novel's main characters." The sea captures the 
contrasts of beauty and sorrow, adventure and loss, the visible and the mysterious, and a sense both of calling and of solitude. "As in the best of all her writing," Epperly writes in a moment of lyrical resonance, "here we find, too, the solemn and the serious alternating with the comic. The harmony of Four Winds, in fact, depends on this alternation as surely as it relies on the rhythm of the sea." $\underline{29}$

Although Epperly's harmonization thesis reads the novel fruitfully, it is difficult to know precisely how light and darkness can be harmonized. Darkness is, after all, the absence of light. Night is distinct from day; starlight, lamplight, and Captain Jim's beacon pierce the darkness. Even blended lights, such as shadow or twilight, are defined by light in contrast to darkness, as we see on the dawn when little joy is born: "the rising sun rent apart the mists hanging over the sandbar, and made rainbows of them." 30 Rather than always harmonizing light and darkness, Montgomery seems content to allow the distinctive contrasts while offering suggestive and unusual relationships between light and dark. Exploring these inviting contrasts provides a glimpse at Montgomery's practical theodicy-making in Anne's House of Dreams.

There are dozens of examples whereby "numerous descriptive passages ... create atmosphere, reflect personality, and suggest the romantic, often symbolic, dimensions" of what Montgomery is capturing in her Four Winds picture. 31 In particular, chapter sixteen, "New Year's Eve at the Light"-an appropriately paradoxical chapter title-begins with the complex contrasts in a winter day that "command our admiration but never our love." Irresolvable contrasts and visual distinctions continue in the narrator's winter description: the harbour is frozen, but the gulf is free; the open white field is imprisoned; a sparkling diamond sky is cut off by stark trees. All of the handsome things in the scene are "ten times handsomer and less attractive in the glaring splendor; and everything that was ugly seemed ten times uglier." For "everything was either handsome or ugly" - there was simply "no soft blending, or kind obscurity, or elusive mistiness in that searching glitter." Lateday pensiveness dims the light but also intensifies it: "sharp angles, glittering points, melted away into curves and enticing gleams. The white harbor put on soft grays and pinks; the far-away hills turned amethyst." Everything is distinctive: even "the shadows were sharp and stiff and clear-cut, as no proper shadows should be." Only the fir trees resist the "crude radiance" of such a piercing light. 32 
There are reasons, then, to reconsider the idea that all things are fully harmonized, for it seems that some contrasts remain. Some of the characteristic features of light, dark, and even shadow remain discrete, resisting any "soft blending." In interrogating Epperly's useful metaphor of "harmony," we come to an intriguing question: What, after all, is harmonized light? Shadow? Fog? Twilight? Dawn or dusk? In each of these cases, the image is still defined by light. Etymologically speaking,

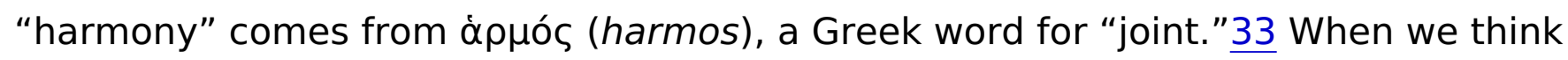
of the nature of light and darkness, how can the two be joined? Some degree of distinction is implied in the definition of the terms, and there is value in reading what remains contrastive and distinctive next to what harmonizes. For, while it is true, as Epperly argues, that Montgomery leaves a gift for her readers in harmonizing many difficult tensions, the distinctive roles of light and dark root the reader's response to the darkness in their respective worlds.

\section{Anne, Leslie, and a Reconstituted Montgomery?}

Not all in the novel harmonizes; neither is all contrariety. Despite all that is lost, the novel resolves the storylines of numerous characters. Anne and Gilbert share a home and find parenthood after loss, Leslie is freed from bondage and finds romance, Owen Ford finds his writerly voice, and Captain Jim sees his life-book in print. Even Miss Cornelia finds a man-although it means the victory of the Grits and the loss of a prodigious beard. When considering these characters and their stories, Epperly convincingly argues that Anne is "twinned" with Leslie through much of Anne's House of Dreams. Leslie likes the struggle and the crash; Anne appreciates the calm and the quiet. Leslie's life is soaked with tragedy, while Anne is (initially) living out her dreams of romance and home life-and yet, these experiences make Leslie the "life counterpart" to Anne. Perhaps, Epperly posits, "Anne and Leslie together are one personality, one psyche split into the ethereal and the passionate." "Towards the end of the novel," Epperly writes, "Montgomery reinforces the harmony between Anne's and Leslie's differences in a number of ways." 34 They are now both "Madonnas," Captain Jim blesses them in a moment of oneness, and, in a scene that supports Epperly's root musical metaphor and my "light" exploration, their laughter harmonizes both visually and sonically: "Anne's laughter was silver and Leslie's golden, and the combination of the two was as satisfactory as a perfect chord in music." 35 It is true, as Epperly argues, that Anne can only initiate friendship, that it takes other things for Leslie to be unbound and restored to wholeness. But that Anne's lost House of Dreams becomes Leslie's romantic 
summer home is a kind of integration that shows how much is harmonized in the contrasts of Montgomery's work.

Other things, however, remain askew or unfulfilled. Not least of these is the bittersweet closure of the novel with Captain Jim's death, the loss of Anne's dream house, and the perpetual disappointment of characters like Susan Baker. Epperly cautiously asks whether the "restored Leslie" is also a "reintegrated Montgomery." 36 Rubio and Waterston provide a series of parallels that suggest Leslie is the shadowy fictional expression of Montgomery's experiences in the period-a supposition that Thompson takes further and one that provides a perceptive thematic connection to my argument. After all, Leslie Moore's initials, L.M., make a tempting link to her creator. 37

If that is the case, however, the most intensely personal of Montgomery's questions of the period remains unanswered-that is, the loss of Hugh Alexander at birth, fictionalized in the brief time between dawn and dusk that little Joy Blythe spends on earth. It is helpful to note the parallels between Anne's House of Dreams and Montgomery's journal. In the novel, Anne cries out in her pain and loss: "'It doesn't seem fair,' said Anne rebelliously. 'Babies are born and live where they are not wanted-where they will be neglected-where they will have no chance. I would have loved my baby so-and cared for it so tenderly-and tried to give her every chance for good. And yet I wasn't allowed to keep her.'" Montgomery's cry of pain in her journal is remarkably similar: "Oh, it is not fair-it is not fair! Children are born and live where they are not wanted-where they will be neglected-where they will have no chance. I would have loved my baby so ... . Yet I was not allowed to have him." 38

Of the parallels between Montgomery's journals and her fiction, the most striking connections are between these late summer 1914 entries of loss and Anne's expressions of grief in Anne's House of Dreams. Within ten days of the outbreak of the war, little Hugh Alexander is lying dead in Montgomery's arms-a personal tragedy spread out into the wearisome, worrisome years of the war. While Anne's voice of protest may find its literary source in Montgomery's journals, one cannot presume a linear relationship that moves from the 1914 journal entries into the novel completed in October 1916. Biographer and journals editor Rubio argues that in recopying her journals after the Great War, Montgomery went through some degree of rewriting and reshaping of her narrative.39 Thus, Montgomery may have rewritten her entries of loss and worry because she was generally pleased with the 
novel and because Anne's grief continued to speak to her. Or it may have been a reflexive process, whereby Montgomery's careful shaping of Anne's questions is intricately bound up with her own journal-writing. In this paper, I am arguing that, in a certain sense, the writing of Anne's House of Dreams is not merely an invitation to a certain way to live in the face of evil that is difficult to understand. More than this, the act of writing is itself Montgomery's practical, ethical response to the problem of evil and suffering in a providential universe. It is an act that goes deeper than merely metaphysical propositions. In writing this tale, Montgomery is standing against evil in the best way she knows how, courageously doing good in the face of unexplainable suffering by telling the story of moral goodness as a moral action-as I argue below that Captain Jim does within the novel. Thus, while it is not essential to determine which is the urtext-the journals or the novel-the possibility that the writing of Anne's House of Dreams helped Montgomery reshape her personal narrative is intriguing - and consistent with the nature of Montgomery's narrative lived theodicy.

The parallels between Montgomery's journals and her fiction are indeed striking. These parallels continue as a grieving Anne tries to discern the divine reasons behind the loss of the child. "It was God's will," Marilla tells Anne, in comfort and secure hope, adding the folk wisdom idea that "little Joy is better off." 40 Anne rejects this theological perspective-what Nancy Huse calls "religious clichés" that prompt Anne to resist "the conventional thinking of Marilla." 41 "I can't believe that," Anne exclaims in her sorrow. What sense does it make, Anne wonders, for a child to be snatched away without a chance to live? "Why should she be born at all-why should anyone be born at all-if she's better off dead? I don't believe it is better for a child to die at birth than to live its life out-and love and be loved-and enjoy and suffer-and do its work - and develop a character that would give it a personality in eternity." $\underline{2}$ In an almost verbatim link between the novel and Montgomery's journal entry for 4 September 1914, both Anne and Montgomery continue to question whether this death is God's will: "Perhaps it was just a thwarting of His purpose by the Power of Evil. We can't be expected to be resigned to that." $\underline{43}$

Marilla's shock at Anne's challenge is one that Montgomery knows well by instinct: the fear that the questions will go too far into "deep and dangerous waters." For Marilla, despair is a kind of journey away from God, dangerous to the body and the soul. Though her initial response was too limited, and though she is worried about losing Anne in her grief, Marilla begins to walk with Anne in her questions. "We can't 
understand," Marilla agrees, "but we must have faith-we must believe that all is for the best." 44 There is something deeper in this comment than the previous claim that all things, good or evil, are God's will-a common belief that is theologically unsatisfying, as it fails to account for the complexity of life or the battle between good and evil that is evident in the novel. Would Marilla consider a sinful act to be God's will? Anne does not immediately claim this necessary faith in the face of suffering but does not reject it either. Whether or not Marilla's more cautious assurances are effective, her practicality has its own productive energy. When questions and creeds have reached their end, Marilla turns to love and duty, encouraging Anne to be "brave" for Gilbert's sake, if for no other reason. This exhortation refocuses Anne in her role as wife, as it would do for Montgomery in her roles as wife, mother, and community and church leader. When Anne's questions seem too great-questions that both Anne and Montgomery are asking in their grief and loss-Marilla's invitation to action and love in the face of unanswerable suffering is significant. And yet, the question of "why?" remains. What does Anne's House of Dreams say about the question of loss and evil and grief in a world where God is supposed to be strong and good?

\section{The Origin of Evil as the Riddle of the Universe}

One of Anne's persistent worries in House of Dreams is her inability to break through the emotional distance between her and Leslie. When she confesses this frustration to Captain Jim, he responds by telling Anne that her life is too filled with happiness: "The barrier between you is her experience of sorrow and trouble. She ain't responsible for it and you ain't; but it's there and neither of you can cross it." By winter moonlight, Anne shares that she had a miserable childhood before Green Gables, but Captain Jim dismisses her sadness as categorically different: "There hasn't been any tragedy in your life, Mistress Blythe. And poor Leslie's has been almost all tragedy." Despite his robust faith_or, as I believe, essential to it-Captain Jim confesses that one of the vast "onunderstandable things in life" is why suffering like Leslie's is permitted. This lack of understanding is not for wont of searching: “The doctor and I have talked a lot abut the origin of evil, but we haven't quite found out all about it yet." 45 Some things seem to work out beautifully, as intended, while other things seem to fail, such as the distance between Leslie's youthful potential and her lot. Captain Jim's "onunderstandable" is what the narrator calls "the riddle of the universe." $\underline{46}$ 
This question of the reality of evil and suffering in the face of Providence runs throughout the entire novel. In chapter one, Marilla has a prophetic realization that "every joy must bring with it its little shadow of sorrow." This presentiment is not without its counterbalance, for in chapter two, Marilla recognizes that good can "come out of the evil" of even ancient pasts. In chapter three, the narrator asserts that "[e]verything works together for good"-assured, in fact, not just by the Bible but also by Reverend Jo, Philippa's husband. Anne seems reconciled to this world-“'IIl willingly accept the sorrow of life with its joy" 47 -although the narrator comments on her limited perspective, wrapped up as it is with joy and love and a waiting House of Dreams.

Even in this short selection of comments early in the novel, we see that Marilla, Anne, and the narrator of their story share a theological perspective on the nature of life. It is this outlook that Anne and Marilla reconsider in their conversation about loss and the meaning of life. While Marilla's view is nuanced by Anne's challenges, neither offers an ultimate answer to the problem of evil in a world where God is good. Rather than resting only on the unanswerable questions or pretending that things are not all that bad-the extremes of despair on one side and denying reality on the other-Montgomery's story offers rooted spiritual perspectives and courageous ethical responses toward the world as it is. This is precisely the theodicy that Montgomery is offering her readers: whatever metaphysical conundrums and "onunderstandable" questions her readers and characters face, Montgomery's story invites readers to live in a certain kind of way in the face of both sorrow and joy. In particular, whatever good or evil may befall us, readers and characters alike are faced with the choice to do good or evil in the warp and weft of everyday life. 48

Although Montgomery could not be aware of the complex philosophical conversation about the problem of evil that is the province of specialists, her narrative lived theodicy anticipates a significant thread in the discourse. Scott argues that, without rejecting philosophical and theological curiosity, all of our intellectual and personal problems can never be fully answered. And yet, our souls demand some way to respond to this intimate problem-as we see in the deftly written conversation between a grieving and rebellious Anne and a grieving and fearful Marilla. In shifting from philosophical questioning to moral action without negating the difficult questions, as Marilla does in that moment of grief and as other characters consistently do throughout the novel, Montgomery anticipates Scott's move from ontological inquiry to spiritual-theological theodicy-making. Scott argues, "Christian 
theodicy does not search for solutions" to the merely intellectual quandary. Deeper than the questions themselves, theodicy-making searches for "theological resources to respond to the problem of evil." Montgomery writes a story that considers the problem of theodicy and offers, in Scott's terms, not "exhaustive answers, but only pathways" of response; thus, Montgomery provides an "experiential, practical" answer to the problem of evil that theologians such as Scott argue is a faithful response both to the reality of suffering and God's providential guidance in the world. 49 Anne's House of Dreams holds together these two realities of unexplainable suffering in the world and God's guiding goodness, never negating either in glib theology or rank cynicism. Montgomery lacks formal philosophical training, and yet she is able to be a "theological resource" for lovers of Anne who are themselves experiencing strains of body and mind and the dark ravages of war.

Within the novel, although Anne has experienced many blessings and much love, she will also experience tragedy and deep sorrow while living in her House of Dreams, leading to her plaintive cry about God's justice and doubts about God's will. Throughout the novel, however, is a picture of evil and good in a constant battle. This struggle is evident in Captain Jim's schoolmaster, where an unknown divinity-good or evil-is living within the man himself. This eerie sense gives the teacher peculiar prescience in a foggy world. For Captain Jim, the lesson is clear: "we mortals all shrink from too close contact with God or devil." Nevertheless, the attraction to the devil remains: "When a man is alone he's mighty apt to be with the devil-if he ain't with God. He has to choose which company he'll keep, I reckon." Keeping company is a leitmotif in the novel, with companionship overbalancing loneliness. Company comes in "dreams and imaginations and pretendings" $\underline{50}$; cats and dogs; books; wind, sea, and the natural world; archangels and human friends. The choice of one's company is critical to the way one lives within the sufferings and joys of the world. The metonymic Captain Jim51 chooses company well and negotiates an optimistic view of the world, despite his realism and his own suffering. When pressed to see if his optimism can wipe away even the devil, Captain Jim prevaricates, "How could a Presbyterian get along without a devil?" But when pressed further, he confesses with some theological subtlety that he believes in "a mighty and malignant and intelligent power of evil working in the universe" who is as evident as God to us mortals. $\underline{52}$

It is this possibility of a malignant, intentional evil that Anne leaves open when she questions whether the death of little Joy, who had never truly had the chance to live, 
is really the will of God or "just a thwarting of His purpose by the Power of Evil." 53 Rubio states that the "sermons Maud heard in the Presbyterian church depicted a dramatic Manichaean universe." 54 In Manichaean dualism, any flesh struggle is lost at the start because the material world-which includes cats and dogs, books and nature, sea and land, lovers and friends-is itself from the dark side. Most of the goodness, friendship, and beauty that Montgomery gives her characters as resources for resisting evil are themselves material realities that counteract the good in a Manichaean universe. Rubio is, however, generally attuned to the dualistic resonances in Montgomery's life, noting how Montgomery's life was "a watchful one, with a constant shifting between brilliant sunshine and deep shadows"55_an image apt to my analysis of Anne's House of Dreams.

Moreover, a dualistic battle of good and evil is waged in Montgomery's fictional world. Those who stand in the good must also struggle against evil. In this vein, Anne argues that they should resist fatalism and refuse to name suffering as necessarily good. Glib resignation to whatever happens is a spiritual failure, for what has happened may actually be aligned with malignant evil that itself resists the good. Marilla admits that it is a difficult intellectual question, but they must keep faith, believing that "all is for the best" - whatever it looks like in the moment. 56 It is here that Anne's questions and Marilla's philosophies could be forever in tension. And yet, Montgomery leaves both realities open in the novel, never resolving them even as, by the end of the tale, Providence seems to have a hand in organizing almost everything for the best.

Although Rubio's point about rich symbolism is valuable, Manichaean dualism inadequately describes Montgomery's theology in her journals or her novels of the period. Contrasting elements of light and darkness or the struggle between good and evil are not to be confused with a stark or defeatist dualism. Rather than a dualistic universe leaking its light as it struggles in the cosmic battle between good and evil, as Montgomery presents it in Anne's House of Dreams, there is a winner in the fight. According to Epperly, Captain Jim is a "living emblem of chivalry and kindness and truth." $57 \mathrm{I}$ argue that he is also the prime theological voice of the novel. As he broaches the topic of evil and the devil, so he imagines this great malignant, intelligent evil force getting "the worst of it in the long run." Whether it is the life-saving medical procedures of Gilbert, the friendships that breach experiential divides, the choice to live with God or the devil, or the grace of God to temper our most extreme reactions, at the "back of it all, God is good." $\underline{58}$ 
Indeed, Captain Jim's faith roots the novel and, appropriate to his job as the lighthouse keeper, provides much of its light-both in terms of humour and also in terms of moral and spiritual guidance. When Anne expresses doubt about reuniting with her dead baby in heaven, he challenges her spiritual imagination: "God will manage better'n that, I believe"-a life truth that Anne eventually comes to discover on her own. At the spiritual climax of the novel, Gilbert mimics Captain Jim's language when he says that God "knew what He was about" after all. $\underline{59}$

\section{The (Spiritual) Life-Book of Captain Jim}

In our philosophical quandaries, Captain Jim has an idea that we as humans rate ourselves overly high on a cosmic level: "I reckon the gods laugh many a time to hear us, but what matters so long as we remember that we're only men and don't take to fancying that we're gods ourselves." As the fireside intellectual adventures are harmless, Jim claims, "let's have another whack at the whence, why and whither this evening, doctor." 60 So Captain Jim continues to ponder "onunderstandable things," unsolvable problems, and metaphysical questions-quite against his father's advice, and knowing that the gods must chuckle at human endeavours. 61 As Captain Jim is the theologian of the novel, his intellectual humility is an embodiment of Montgomery's perspective about the problem of evil in a world guided by a good God.62 Even though one's perspective may simply be too limited to see the entire story in play, the searching can continue. Epperly extends this perspective to all of the characters, arguing that the "fact that no one is always right seems a deliberate part of Montgomery's philosophy in the novel." The significance of Montgomery's philosophical approach, Epperly argues, is that the speculative world of Four Winds works as a microcosm for the primary world of writer and reader:

Just as Four Winds is an idealized version of the world-a place where all things harmonize, where even ugliness and violence are admitted, though they do not triumph-so it is also a miniature of the world Montgomery knew, and in it all people have lessons to learn or gaps in their understanding that others may discern but that they themselves may be incapable of discerning.

Epperly observes that the narrator, rather than being pedantic, is sympathetic to the reader, bridging the gap between reader and character as they explore the "conflicting tendencies" in the novel. 63 
Again, however, are all things harmonized? Rather than "harmony" being the most crucial aspect of this shared, limited perspective, the limitation serves to shift the question back to one's response to ugliness and violence. For Captain Jim, who tethers himself to what is knowable while unafraid of unanswerable questions, humility is a critical starting point. A person's attitude to what can and cannot be known and one's ethical response before the world are critical features of Montgomery's model for how to respond in a theologically integrated way to the problem of evil in the world.

On a practical level, recalling that ethical response is critical to Montgomery's narrative theodicy, the choices that characters must make in this novel are not easy or straightforward-and neither do they fall simply into categories of good and evil. For Anne to move to the House of Dreams is to leave beloved Avonlea, kith and kin and memories of being loved for the first time. At the end of the novel, Anne and Gilbert must leave behind their House of Dreams for the practicality of life and work and family. As a young girl, poor Leslie is torn between obedient love for her bereaved mother and the dark horror of marrying Dick Moore. When the man she believes to be her husband, George Moore, returns to the Island as an adult infant, Leslie must, for the sake of morality and goodness, stay in his life, caring for him until his death while suffering her own bitterness and poverty. This man is in Leslie's life because Captain Jim has made the costly choice to bring him home, devoid of memory as he was. Gilbert must deepen that wound by offering to provide his patient with medical help that would return him to adult intelligence but threaten the return of his cruelty and unfaithfulness.

Part of the riddle of the universe, the problem of evil, is the fact that choice is a risk. Love is a risk, so that lovers and friends will experience both joy and sorrow in the very act of loving and being loved. In Anne's mundane choice to have children, there is the danger of Leslie's bitter envy and the deep sadness of loss. In a novel of penetrating subtlety and complexity, all of the major decisions in Anne's House of Dreams are weighty and leave someone uneasy. In almost every case, the main characters take up the impossible, terrible good and live with that choice.

Effectively, in limiting the knowledge of the ultimate plan, the "good" working behind all things, Montgomery shifts the foundation of the problem of evil to the question of what a character will choose to do-from a metaphysical quandary to a crisis of lived spirituality, "a transition from the theoretical to the practical, from the abstract to the concrete, from the global to the particular." $\underline{64}$ 
In this, Captain Jim is one of the models of living well amid sorrow, ugliness, stupidity, faithlessness, and violence. Captain Jim may struggle with philosophical "onunderstandables," but he is poised for moral action. He describes how, the previous winter, he found a cat dead on the shore, frozen to death while protecting her kittens. Captain Jim first cried out in lament to the Lord. Then he swore. Then he cared for the kittens, feeding them and giving them to good homes. Captain Jim's responsibility did not end there, however. He felt he must confront the person who left the cats to die, reminding her of her Christian responsibility before God. And, finally, Captain Jim tells the story, which works as both history and parable, presenting Captain Jim's character as a moral model and leaving a pathway for the reader to respond to tangible evil in the everyday world. $\underline{65}$

In this context of Jim's response to a small but significant act of moral evil, we see the more difficult decisions of the novel. For Captain Jim, doing the right thing, in this case, was not difficult. Choosing right was almost as habitual as his "habit of enj'ying things" and the "rank meddling" that creates so much of the friendly humour between him and Miss Cornelia. Throughout the novel, Captain Jim chooses to show fidelity to the schoolmaster even when he is fearful about his eerie gifts or jealous of his new lover. Captain Jim chooses to take home the man he believes to be Dick Moore and later advocates for his surgery-although he regrets the pain he is causing Leslie, whom he loves and favours. In the face of dockside misogyny, Captain Jim rises in righteous wrath, "the lightning of his eyes ... a man transformed." 66 He risks telling Anne amid her own grief of his Lost Margaret. And he shows fidelity to Lost Margaret all his life, including telling her story and ensuring that others will tell it as well.

For storytelling is essential to moral action-and, in Scott's terms, a critical aspect of theodicy-making. 67 As Montgomery shifts the frame of theodicy from philosophical "onunderstandables" to moral response, Captain Jim demonstrates that telling stories is one of the morally good things we do in the face of evil that we cannot understand. In this way, the lighthouse and its keeper, Captain Jim, work metonymically and metaphorically, as Epperly notes. But storytelling also works representationally, allowing the narrative cycles within the novel to capture the essence of Montgomery's storytelling in a kind of literary mise en abyme. Captain Jim tells stories to challenge the "thoughtless" cruelty of the world, $\underline{68}$ comfort Anne in her grief, make allies on the side of good, and keep Lost Margaret's memory alive. Captain Jim's stories work to stand against evil and to cope with suffering. 
Moving one frame out, Montgomery herself writes amid physical and mental strain, and in a period of loss and war, in order "to give form, shape, and sound to the pain of losing" and to bring "structure and order to the chaos of grief"-words of Richard Stamelman and Susan Zimmerman, respectively, that Melanie Fishbane uses to conceptualize Montgomery's approach to writing. $\underline{69}$ In assessing Montgomery's writing in response to her pain, Fishbane notes that " $[\mathrm{w}]$ ]ords also have the power to bring solace to a grieving heart." 70 The "writing out of a pain makes it at least bearable," Montgomery admits in her journal after the loss of her grandfather, an evening when "the shadows have gathered thickly" in her world, both literally and metaphorically. Montgomery feels "born of sorrow and baptized of suffering ... the sister and companion of regret and hopeless longing."71 But she writes for her own "emotional well-being," as Fishbane terms it, and conceptualizes this act within her characters' experiences.72 Beyond self-care, as her sorrows heighten in the wake of the First World War and the loss of her newborn child, Montgomery creates fiction that, in Epperly's words, is "a tightly woven, wise story" with philosophical depth that faces grief and pain within the story as it stands against the war and change and evil in Montgomery's own world.73

Thus in providing comfort and meaning and shaping a moral response, Montgomery's story for a war-ravaged public in the primary world does what Captain Jim's stories do within the tale. It is not that we stop asking questions or ignore the dark realism of our lives, for talking about "the origin of evil" and other imponderables has value in itself. Captain Jim does not disappear into the suffering, darkness, and evil of the world or allow "the riddle of the universe" 74 to restrict his moral response to the problem of evil in a providential world. Instead, Captain Jim lives out his faith bravely and ethically, standing against moral evil and telling stories that operate like a beacon guiding travellers on dark and stormy seas to the shore.

\section{Making Friends with the Darkness: Montgomery's Lived Theodicy}

Because, as Epperly correctly observes, "the whole book asks, where is the virtuous and admirable life?" 75 Captain Jim is, appropriately, the lightkeeper-a metonymically profound literary device as light remains the symbolic and imagistic centre of a novel that has a good deal of shadow and darkness in it. Epperly's focus upon light and colour in Anne's House of Dreams is a fruitful reading of the text as it draws out critical elements of a "Four Winds harmony" that Montgomery creates for 
the reader. In this paper, my approach has been to "interrogate" the text in order to "generate" new meaning. By troubling the metaphor of "harmony"-without negating its thematic value-I have demonstrated that light and darkness are interrelated in complex ways in the novel, but, as contrasts, they cannot be altogether harmonized. At the risk of pressing the metonymic value of Captain Jim as lightkeeper too far, there is a moment in one of the novel's many nocturnal scenes that is symbolically meaningful for Montgomery's experiment in narrative theodicymaking as I have captured it here. Anne and Captain Jim are walking in silence after Anne has caught Leslie Moore in the depths of grief and sorrow:

Presently Anne said, "Do you know, Captain Jim, I never like walking with a lantern. I have always the strangest feeling that just outside the circle of light, just over its edge in the darkness, I am surrounded by a ring of furtive, sinister things, watching me from the shadows with hostile eyes. I've had that feeling from childhood. What is the reason? I never feel like that when I'm really in the darkness-when it is close all around me-l'm not the least frightened."

"I've something of that feeling myself," admitted Captain Jim. "I reckon when the darkness is close to us it is a friend. But when we sorter push it away from us-divorce ourselves from it, so to speak, with lantern light-it becomes an enemy. But the fog is lifting." $\underline{76}$

It is an intriguing transformation of metaphor: within a novel with light at its centre, Montgomery images a spiritual danger to light as it can create a fiction of safety and divorce us from the necessary companionship of darkness. The darkness is essential to life and never far from us. It would be possible to press this image out of shape and overdetermine the relationships of darkness, suffering, and evil. However, practically, theologically, and morally, we must befriend the darkness-or at least come to terms with the darkness and shadow as we sojourn in it. In terms of the novel's themes, attempting to banish the sorrows and difficult life questions will make the darkness only more alienating. Even in the novel's conclusion, sorrow and happiness are knit together in the narrator's vision of the future, Anne's inner thoughts, and Captain Jim's final benediction. $\underline{77}$

In this way, Montgomery's darkness, shadow, and gloaming images within Anne's House of Dreams provide a striking contrast to many of her poems in The Watchman and Other Poems, gathered together while Montgomery was working on Anne's House of Dreams.78 While the lyric poems share the imagery of the novel, the 
poems are far less comfortable with complexity than the novel. So few of the pieces retain the darkness as a contrast to the light or allow the sorrow to pair with the beauty-"the struggle-and the crash-and the noise," which inspire Leslie's love of the sea after a storm, or the "effects of light and shadow" that Anne loves so much. 79 Even a poem about loss like "As the Heart Hopes" lacks the edge of darkness as the poetic voice washes all in pale colours: "A hundred universes you may roam, I But still I know-I know-your only home / Is here within my heart!" 80 Near the end of the collection, there are more poignant moments of death and loss and winter. But Montgomery seems too interested in putting "tears and memories away" than watching as "twilight weaves its tangled shadows all / In one dim web of dusk." 81

Although set beside and on the sea, there are very few storms in the poems. By contrast, the journeys of the characters in Anne's House of Dreams are perilous. In Montgomery's "When the Dark Comes Down," the sea is a "lisping laugh," and "every wave's a lyric when the dark comes down." 82 In the poem's romanticism of a seafarer's life, the alliterative metaphors lack the authenticity of the dissonance and harmony of Anne's House of Dreams-both joy and suffering, success and strains of body and mind, the struggle and the crash, and effects of light and shadow. As argued throughout, images of darkness and the sea are critical to the movements of joy and sorrow in Anne's House of Dreams. Without the stormy parts of the novel, Montgomery's imaginative lived theodicy would lack its compelling immediacy. "You can weather any storm," Captain Jim says, with "love and trust ... for compass and pilot." Even with happiness, "troubles and worries and sorrows" are "bound to come." But the Lord knows what is right, "as a good Captain should." 83

Anne's House of Dreams, then, is the picture of a creative experiment in narrative lived theodicy for everyday readers that contains a robust message: behind all the beauty and tragedy, all the love and loss, all the sadness and sorrow and holy laughter, the great Captain of creation knows best. Montgomery holds all of these tensions together, harmonizing many of them but also allowing some of the contrasting elements to remain in the novel's narrative arc. True, the "happy ending strains credulity," 84 and Montgomery could have perhaps trusted her readers with more of the tensions in play. But on a philosophical level, Montgomery offers a coherent message while refusing to blur the edges of the contrast. However many conversations Captain Jim hosts at the lighthouse, the puzzle of the "problem of evil" may never be solved on a metaphysical level. Nevertheless, there is a practical approach to Montgomery's spirituality in this piece, a philosophy of life that 
recognizes the contrasting sorrow and hopefulness and a great battle between evil and good in real life and yet trusts in the greater good of love and friendship and Providence. As Scott argues nearly a century later, with a practical perspective to the problem of evil, "ethics ... becomes a new frontier of theodicy" in a way that does not negate the difficult questions.85 One cannot eliminate darkness from life. Giving in to shadows or disappearing into the darkness is deadly, but pretending that there is only light and joy is also not an option. One must, like Captain Jim, make friends with the darkness, for the contrast between darkness and light, between dawn and dusk, gives light and day both definition and meaning.

\section{Montgomery's Narrative Lived Theodicy in the Philosophical Tradition}

Theodicy-making has a sophisticated philosophical and theological tradition, from the Hebrew Bible, Plotinus, St. Irenaeus, and St. Augustine of the classical world and through the ages to leading post-war thinkers such as John Hick in Evil and the God of Love, Richard Swinburne in The Existence of God, Peter van Inwagen in The Problem of Evil, and Alvin Plantinga in God, Freedom, and Evil, among other works. More responses for non-specialists include Roman Catholic Pope John Paul II's theology of the body, American spiritual essayist Annie Dillard's Pilgrim at Tinker Creek, Orthodox theologian David Bentley Hart's The Doors of the Sea, Jewish rabbi Harold S. Kushner's When Bad Things Happen to Good People, and recent books and talks by evangelical theologian Gregory A. Boyd, world-religion scholar Karen Armstrong, and Christian disabilities activist Joni Eareckson Tada. Theodicy-making is a long tradition at the university podium and in the church pulpit, but also in the pew, with popular and artistic responses to the problem of a world that is both providential and full of suffering.

Montgomery's narrative theodicy, as I have described it here, is instinctive, emerging from her personal contexts, questions, and perspectives. And yet it anticipates Christian theological and philosophical approaches to theodicies of the century that would follow, as we have seen in the writing of philosophical theologian Mark Scott but also in the work of lay theodicy-makers. Before he was the author of The Chronicles of Narnia, twentieth-century literary historian and Anglican C.S. Lewis, attempted a theodicy for non-academic readers in his Second World War-era volume, The Problem of Pain. No doubt evoking a line from John Keats, Lewis anticipates Hick's "Soul-Making Theodicy" by arguing that "the world is indeed a "vale of soul making'" and that "it seems on the whole to be doing its work." $\underline{86}$ 
Keats, Hick, and Lewis seem to share the same poetic and philosophical instincts as Faith Meredith, one of the manse children of Rainbow Valley, the novel to follow Anne's House of Dreams. At her father's church doorstep, Faith challenges a dour church lady by declaring that the "world isn't a vale of tears ... . It's a world of laughter." 87 Like Keats, Hick, and Lewis, Faith wants to challenge the idea that life is defined by sorrows and tragedy. Anne's House of Dreams shows both the tears and the laughter and, in doing so, offers a practical, ethical, and deeply theological response to the darkness and shadows of the world. Lewis's Narnian fairy tales and speculative fiction presuppose his war-era soul-making theodicy; in a similar vein, though lacking an academic context, Montgomery is able to offer a narrative soulmaking theodicy that is personally satisfying without being philosophically neglectful.

Montgomery's instinctive lived theodicy also anticipates that of Anglican priest N.T. Wright in his lecture series-turned-book, Evil and the Justice of God. Wright argues that there are philosophically defensible reasons to believe in a good God in a world haunted by evil. For a general audience, Wright illustrates the arguments of leading philosophers with the ideas of figures such as Nazi-resisting pastor Dietrich Bonhoeffer, liberation theologian Jürgen Moltmann, and Croatian-American theologian Miroslav Volf, who reflects on ethnic cleansing in his home country. Wright also includes poets and novelists writing in a tradition that resonates with Anne's House of Dreams. Wright would agree with Captain Jim (and Mark Scott) that, ultimately, the problem of evil is an "onunderstandable": "We [humans] are not told-or not in any way that satisfies our puzzled questioning-how and why there is radical evil within God's wonderful, beautiful and essentially good creation." Like Montgomery, Wright invites the reader to imagine the power of accepting the darkness while resisting evil with the hope that good will ultimately overcome how we "live with the fact of evil in our world." Intriguingly, like Captain Jim in approach and Montgomery in her work as a novelist-and resonant of the "sea" imagery that Epperly explores in Anne's House of Dreams-Wright provides a response to the problem of evil that includes these same steps: considering the problem, thinking critically about it, forming a moral response, and then telling the story "in such a way that, without attempting to 'solve' the problem in a simplistic way, we can nevertheless address it in a mature fashion, and in the middle of it come to a deeper and wiser faith in the creator and redeemer God whose all-conquering love will one day make a new creation in which the dark and threatening sea of chaos will be no more." $\underline{88}$ 
Albeit far more formal in philosophical treatment than Montgomery's narrative consideration of light and darkness, these approaches by Lewis, Wright, and Scott contain a similar trajectory. While it is important to see the darkness, name the evil, and recognize suffering, what is critical is the practical, lived-experience response of resisting evil, supporting those who suffer, coming to terms with darkness, and telling stories that provide light in the midst of the darkness.

\section{Conclusion: Captain Jim's Light and a Lantern at Montgomery's Back}

Montgomery's biographers will undoubtedly struggle to understand how to reconcile this robust and instinctive theodicy in fiction with Montgomery's personal challenges, doubts, and fears-especially given the biographical links that critics such as Rubio, Epperly, Cowger, Drain, Gerson, and Thompson make with the novel. 89 After all, there is an alluring temptation to harmonize the writer's fiction and the writer's philosophy, particularly given how philosophically complex both the novel and the intimate links back to Montgomery's journals are. 90 As Epperly notes, negotiating the tensions between "the fiction and (supposed) non-fiction" of Montgomery is something scholars must do.91 Perhaps, in Simone Nelles's analysis, Montgomery's faith is best described as "Pilgrimages in a Land of Penumbra," a journeying land of only partial illumination.

I am arguing in this paper that there is value in appreciating Montgomery's experience in writing Anne's House of Dreams in the context of war and loss. The precise links between the novel and Montgomery's journals are compelling evidence of the interrelationship between Montgomery's personal life and the shadows, darkness, and nuance that she writes into this novel. And yet, I have resisted readings that might privilege the journals or attempt to resolve altogether the biographical and literary tensions. Montgomery makes links between her life and her novels; however, she also resists over-reading these connections, for " $[t]$ here are a good many of L.M. Montgomery's sides they don't see [in my novels]." 92 As a public figure and novelist, during her lifetime Montgomery chose to remain in the shadows when it came to her deepest sense of self-a choice that provides challenges to scholars attempting to present a concise picture of her faith and worldview.

In her 2014 preface to The Fragrance of Sweet-Grass, Epperly narrows in on the imagery that I have used in this study to consider the biographical element: "The inner and outer (private and public) tension is also allied to other forms of contrast-most commonly, dark and light."93 Reviewer Faye Hammill writes that the 
darkness of Montgomery's journals creates an "enormous distance from the sunny world of her novels." 94 Given my analysis, I argue that Hammill overdraws the contrast. A close reading of Anne's House of Dreams clearly demonstrates a sophisticated metaphorical use of darkness, light, and shadow. The characters resist darkness, but they also must come to terms with it-indeed, befriend the darkness as they struggle against it-in order to appreciate the light. "Contrasts and tensions are vital," Epperly argues, to Montgomery's "uses of metaphor, of how she suggests multiple meanings and levels of meaning." 95 A careful reading of Montgomery's journals may also demonstrate a more sophisticated juxtapositioning of light and darkness, to use Rubio and Waterston's evocative phrase, which Montgomery writes into her own life and transmutes into her stories. 96

Anne's House of Dreams, in particular, invites comparisons that no doubt tempt reader and scholar alike. Whatever biographers conclude, any attempt to reconcile these contrasting and harmonizing images in a single, unambiguous image of the author's religious views or philosophical conclusions is bound to negate either darkness or light in a way that is inorganic to the novel that Montgomery wrote in the midst of "the holy passion of motherhood" and the situational "strain of mind and body" of war, depression, worry, and loss. In Montgomery's own life, not all the endings were good ones. While she may have shared the view that there is a greater good behind our difficult moments and that we should respond faithfully to evil and injustice, it is unclear whether Montgomery herself was able to befriend the darkness as easily as Anne and Captain Jim could. However, as Dillard notes in Pilgrim at Tinker Creek, "shadows define the real."97 Even though Montgomery could not always make friends with the darkness herself, she remains an author offering hope to readers much like the image of light in Dante's Purgatoria: "Thou was as one who, traveling, bears by night / A lantern at his back, which cannot leaven / His darkness, yet he gives his followers light." 98 In this way, as a storyteller, Montgomery is a literary lighthouse keeper. Whatever personal doubts she may have retained in life, like Captain Jim, Montgomery told stories that give light to the world, model and inspire moral action, and resist evil, chaos, and darkness-the principles of her narrative, life-embedded, soul-making theodicy. Writing Anne's House of Dreams was Montgomery's practical, ethical, wartime response to unexplainable suffering and unanswerable questions in a world filled with both sorrow and joy. 
As both light and darkness define our experience in this world-as well as shadows, fog, mist, dawn and dusk, twilight and starlight, and both darkness and light in eyes, on faces, and in spirits-so Montgomery's most philosophical and poetical novel is filled with contrast. No doubt, some of the furtive, sinister, hostile things in the darkness turn out to be just shadows when the light streams in-although shadows have their own danger and beauty. Montgomery's novel revels in love and joy and friendship, but it is also filled with lost years, shattered dreams, buried hopes, and solitary gravestones. Happy endings do not erase the stories of Dick Moore, Lost Margaret, and little Joy, whom Anne is not allowed to keep. And, in the end, the dawn that brings the light also invites the loss of those we love. As we discover in reading Montgomery's instinctive, non-specialist, emergent theodicy in story form, shared darkness can bridge a gulf between friends and transform how we live in a providential world of both deep sorrow and unspeakable joy.

Acknowledgements: I would like to acknowledge the particularly strong feedback, critique, and support I have received during the process of editing this paper. At each stage, editors Lesley Clement and Tara K. Parmiter provided insightful comments and incisive critiques, allowing each draft to be stronger and clearer than the one before. More than this, I would like to thank the anonymous peer reviewers and the committee members of the Epperly Award for Outstanding Early Career Paper, for which this paper was a submission. Each of these readers took seriously what is a complex experiment in theology and literature-to take a non-academic, popular writer and demonstrate that her intensely personal novel reveals a sophisticated use of imagery that provides a philosophically satisfying response to one of life's most difficult questions. In reading this experimental piece, the peer reviewers and committee members provided overwhelmingly helpful encouragement, guidance, and critique.

Banner image derived from Everybody's Magazine. 1906. KindredSpaces.ca, P103 E $1906.02 \mathrm{P}$

- 1 Montgomery, CJ 3 (5 Oct. 1916): 248-49.

- 2 Epperly, Fragrance 75; see Thompson, "Shadow" 113, 124; Vincent, Memorialisation 87n9; Edwards and Litster, "End" 33, 43. 
- 3 Montgomery, CJ 2 (15 Oct. 1908): 199.

- 4 Thompson 113-30; Edwards and Litster 43.

- $\underline{5}$ Epperly 87, 75, 84.

- 6 Walton, Literature 1.

- 7 Montgomery, AHD 103.

- 8 Scott, Pathways xi.

- 9 Plantinga, "Supralapsarianism" 2; quoted in Scott, Pathways xi.

- 10 Scott, Pathways 56; Scott quotes Paradise Lost 1.26.

- 11 See especially chapter 15.

- 12 Epperly 87.

- 13 Scott, Pathways xiii.

- 14 Montgomery, AHD 117.

- 15 Scott, Pathways 59. Captain Jim says to Anne, "There's a vast of onunderstandable things in life, ain't there, Mistress Blythe? Sometimes things seem to work out real proper-like, same as with you and the doctor. And then again they all seem to go catawampus" (Montgomery, AHD 103).

- 16 Montgomery, CJ 3 (22 Sept. 1912): 73. It must be noted that this comment concludes quite a complex response to new motherhood, full of fear, self-doubt, sensual and sentimental descriptions, religious questions, and profound statements of love. "Motherhood is heaven," Montgomery writes near the beginning of the entry, and adds a haunting follow-up comment: "It pays for all" (68).

- 17 Montgomery, CJ 3 (30 Aug. 1914): 163.

- 18 See Rubio, Lucy Maud Montgomery 193.

- 19 Montgomery, CJ 3 (10 June 1916): 229.

- 20 Rubio, Lucy Maud Montgomery 201.

- 21 Rubio and Waterston, Introduction x; see Montgomery, Among the Shadows 15; Epperly 146.

- 22 Rubio and Waterston, Introduction x.

- 23 Thomas, "Decline" 39; Vincent 87n9, in dialogue with Edwards and Litster 43.

- 24 Cowger, "Pretty" 196.

- 25 Rubio, Lucy Maud Montgomery 197.

- 26 Thompson 113.

- 27 Epperly 75, 86-7.

- 28 Montgomery, AHD 66; Epperly 88.

- 29 Epperly 87, 75, 81, 76, 91. 
- 30 Montgomery, AHD 114.

- 31 Epperly 75.

- 32 Montgomery, AHD 96.

- $\underline{33}$ "harmony, n."

- 34 Epperly 85, 79, 79, 85.

- 35 Montgomery, AHD 191, 203.

- 36 Epperly 79.

- 37 Rubio and Waterston, "Afterword" 282-83; Rubio, Lucy Maud Montgomery 198. Epperly argues that shadowed side of Anne is embodied in Leslie (78).

- 38 Montgomery, AHD 117; Montgomery, CJ 3 (30 Aug. 1914): 163.

- 39 Rubio, Lucy Maud Montgomery 274. Thanks to Tara Parmiter for reminding me of the complexity of precise journal dating in the period.

- 40 Montgomery, AHD 117.

- 41 Huse, "Journeys" 61.

- 42 Montgomery, AHD 117-18.

- 43 Montgomery, AHD 118; Montgomery, CJ 3 (4 Sept. 1914): 165-66.

- 44 Montgomery, AHD 118.

- 45 Montgomery, $A H D$ 102, 103. On tragedy in Anne's life, Lisa DeTora notes that as "the novel progresses, continual reference is made to the possibility for deeper and more profound tragedy than Anne Shirley had ever encountered" ("After" 4).

- 46 Montgomery, AHD 117.

- 47 Montgomery, AHD 2, 8, 16, 18.

- 48 For an approach that aligns reader and character, see Frever, "Seeing." Epperly includes the scholar in the reader category in her 2014 preface to The Fragrance of Sweet-Grass, esp. p. xiv, and in the introduction, where she describes the reader as "we" for five critical reasons: 1 ) she loves Montgomery's books and truly is a reader; 2 ) there is an imaginary and idealized reader that is as "real" as the narrator in a story; 3 ) she agrees with the reader-response theory of Jonathan Culler and Stanley Fish; 4) she resonates with Rachel Brownstein's idea in her monograph Becoming a Heroine: Reading About Women in Novels (see p. xix) that readers read about heroines because they want to be heroines; and 5) she likes "to think that many of 'us' may truly share perspective or values or questions-alongside our radical differences in interpretations-in assessing a woman writer's assessment of women" (13). So, while Epperly can write that the "customary border between 'fan' and 'scholar' can be meaningless concerning study of 
Montgomery's writing and life" ( $\mathrm{xx}$ ), there is no doubt that as a male reader and scholar, I would need to recalibrate the fourth and fifth reasons.

- 49 Scott, Pathways 2, 3-4, 59.

- 50 Montgomery, AHD 33, 91, 66.

- 51 Epperly 86-7.

- 52 Montgomery, AHD 111.

- 53 Montgomery, AHD 118.

- 54 Rubio, Lucy Maud Montgomery 35. It is possible, of course, that Rubio simply means "dualism": light and dark, good and evil, heaven and hell, etc.

- 55 Rubio, Lucy Maud Montgomery 105.

- 56 Montgomery, AHD 118.

- 57 Epperly 86-7.

- 58 Montgomery, AHD 111, 110.

- 59 Montgomery, $A H D$ 120, 206. For a study on theological imagination, see Golding Page, Kindred, esp. iii; 30-3;120-34; Hilder, "Unholy"; Hilder, "Imagining"; Nelles, "Pilgrimages"; Sorfleet, “Pagan”; Steffler, “Being a Christian"; White, "Religious." See also Kessler, "Creation” 234.

- 60 Montgomery, AHD 86.

- 61 "'I like to ponder on all kinds of problems, though I can't solve 'em,' said Captain Jim. 'My father held that we should never talk of things we couldn't understand, but if we didn't, doctor, the subjects for conversation would be mighty few'" (Montgomery, AHD 86).

- $\underline{62}$ On humility as a key spiritual virtue, see Rubio, "Scottish-Presbyterian" 93.

- 63 Epperly 89.

- 64 Scott, Pathways 58.

- 65 Montgomery, AHD 58.

- 66 Montgomery, AHD 105, 58, 61.

- 67 Scott, Pathways 56.

- 68 For Captain Jim, "the worst kind of cruelty" is "the thoughtless kind" (Montgomery, AHD 58).

- $\underline{69}$ Quoted in Fishbane, "My Pen" 131; Stamelman, Lost 19; Zimmerman, Writing 18.

- 70 Fishbane 137.

- 71 Montgomery, CJ 1 (8 Apr. 1898): 388-89.

- 72 Fishbane 141.

- 73 Epperly 75.

- 74 Montgomery, AHD 117. 
- 75 Epperly 94.

- 76 Montgomery, AHD 85-6.

- 77 See Montgomery, AHD 213-14, 224.

- 78 Epperly 75-6.

- 79 Montgomery, AHD 64, 66. It is worth noting how these two perspectives in the twinned relationship of Anne and Leslie bring together Epperly's aural metaphor (harmony) and my visual metaphor (light, darkness, and shadow) as they hold together the contrasting and complementary elements of danger and beauty. struggle and joy.

- 80 Montgomery, Watchman 95 ("As The Heart Hopes," lines 30-2).

- 81 Montgomery, Watchman 153 ("While the Fates Sleep," lines 17, 15-6).

- 82 Montgomery, Watchman 14-5 ("When the Dark Comes Down," lines 2, 18).

- 83 Montgomery, AHD 214, 52.

- 84 Rubio, Lucy Maud Montgomery 199.

- 85 Scott, Pathways 59.

- 86 Lewis, Problem 96. See Scott, "C.S. Lewis" 26.

- 87 Montgomery, RV 22. See Dickieson, "The World."

- 88 Wright, Evil 98, 26, 27.

- 89 See also Margaret Steffler's observations in her study, “'Being a Christian' and a Presbyterian in Leaskdale," on how religion draws together various ways that Montgomery shapes her story. Notably, Steffler uses images like darkness and shadow to describe Montgomery's relationship with religion, including the "dark undercurrent pertaining to religion" (64), an "inclination to spiritual darkness" (67), the "shadow" of Montgomery's grandmother's religion (61), and, poignantly, how Montgomery's "rather tame (even at the time) religious transgression distracts both Montgomery and the journal reader from the shadow of much stronger and darker emotions that do threaten her religious faith and already exist in a muted form in the Cavendish years. These shadows emerge and expand in her religious struggles in Leaskdale as she performs her demanding roles as minister's wife, famous writer, and concerned mother" (66).

- $\underline{90}$ Rubio's Montgomery biography, Lucy Maud Montgomery: The Gift of Wings, is to some degree a chronicle of the difficulty in aligning Montgomery's journals (and letters) with her public persona in the novels and her self-presentation in autobiographical notes, speeches, and essays-and, indeed, with the figure that resounds in the memories of those who knew Montgomery in everyday life, as captured in Rubio's work as an oral historian. Perhaps her clearest articulation 
of how she negotiates the tension is in her 1999 article on "Scotch-Presbyterian Agency": "L.M. Montgomery's view is not necessarily that of her characters, of course. She stands enough outside them that she knows when their viewpoint ... will sound quite comical ... . In other cases, she takes aim at those whose practice of religion misses its spirit. However, Montgomery's point of view is very complex and often unstable, and it changes at different points in her life. The Montgomery who writes the novels is often not the Montgomery who writes the journals" (97; see also Klempa, Passionate). It is arguable whether these are different people writing-Montgomery preferred the image of "sides" to her personality (CJ 5 (31 Dec. 1923): 190)—but Rubio demonstrates well the complexity of the task of biography-making and biographical criticism.

- 91 Epperly xxvii; see Rubio, Lucy Maud Montgomery 1-9, 54; to further complicate the biographical project, see Woster, Intertextuality.

- 92 Montgomery, CJ 5 (31 Dec. 1923): 190.

- 93 Epperly xxvii.

- 94 Hammill, "Something" 21; quoted in Epperly xxvii. See also Golfman, "Bleak" 25.

- 95 Epperly xxviii.

- 96 Rubio and Waterston, "Afterword" 282.

- 97 Dillard, Pilgrim 63.

- 98 Dante, Purgatory 242, Canto XXII, lines 67-9.

Back to top

\section{Article Info}

(c) $\mathrm{EY}$ Copyright: Brenton Dickieson, 2021. This work is licensed under a Creative Commons Attribution 4.0 International License (Creative Commons BY 4.0), which allows the user to share, copy and redistribute the material in any medium or format and adapt, remix, transform and build upon the material for any purpose, even commercially, PROVIDED the Licensor is given attribution in accordance with the terms and conditions of the CC BY 4.0.

Peer reviewed

Yes

Works Cited 
Bode, Rita, and Lesley D. Clement, editors. L.M. Montgomery's Rainbow Valleys: The Ontario Years, 1911-1942. McGill-Queen's UP, 2015.

Brownstein, Rachel M. Becoming a Heroine: Reading About Women in Novels. Penguin, 1984.

Cowger, Ashley. "From 'Pretty Nearly Perfectly Happy' to 'the Depths of Despair': Mania and Depression in L.M. Montgomery's Anne Series." The Lion and the Unicorn, vol. 34, no. 2, Apr. 2010, pp. 188-99.

Dante. The Divine Comedy 2: Purgatory. Translated by Dorothy L. Sayers, Penguin Books, 1955.

DeTora, Lisa. "In After Years: Retrospection and the Great War in the Work of L.M. Montgomery." 49th Parallel, vol. 5, 1999-2000.

Dickieson, Brenton D.G. "C.S. Lewis's Theory of Sehnsucht as a Tool for Theorizing L.M. Montgomery's Experience of 'The Flash.'" The Faithful Imagination: Papers from the 2018 Frances White Ewbank Colloquium on C.S. Lewis and Friends, Taylor University, edited by Joe Ricke and Ashley Chu, Winged Lion P, 2019, pp. 144-65.

-. "Rainbow Valley as Embodied Heaven: Initial Explorations into L.M. Montgomery's Spirituality in Fiction," The Journal of L.M. Montgomery Studies, 2020, https://journaloflmmontgomerystudies.ca/reading/dickieson.

-. "The World as a 'Vale of Soul-Making': A Brief Note on John Keats, C.S. Lewis, and L.M. Montgomery." A Pilgrim in Narnia, 21 May 2020, https://apilgriminnarnia.com/2020/05/21/a-vale-of-soul-making/.

Dillard, Annie. Pilgrim at Tinker Creek. HarperPerennial, 1998.

Drain, Susan. "Telling and Retelling: L.M. Montgomery's Storied Lives and Living Stories." Canadian Children's Literature/Littérature canadienne pour la jeunesse, vol. 81, spring 1996, pp. 7-18.

Edwards, Owen Dudley, and Jennifer H. Litster. "The End of Canadian Innocence: L.M. Montgomery and the First World War." Gammel and Epperly, pp. 31-46.

Epperly, Elizabeth R. The Fragrance of Sweet-Grass. 2nd ed., U of Toronto P, 2014. 
Fishbane, Melanie J. "'My Pen Shall Heal, Not Hurt': Writing as Therapy in Rilla of Ingleside and The Blythes Are Quoted." Bode and Clement, pp. 131-44.

Frever, Trinna S. "Seeing Female Readers, Reading Female Readers, Making MetaReaders: L.M. Montgomery as Depictor and Creator of Scholars," keynote speech for the L.M. Montgomery Institute's 13th Biennial Conference, University of Prince Edward Island. Published Feb. 24, 2020, in the Journal of L.M. Montgomery Studies, https://journaloflmmontgomerystudies.ca/reading/frever.

Gammel, Irene, and Elizabeth Epperly, editors. L.M. Montgomery and Canadian Culture. U of Toronto P, 1999.

Gerson, Carole. “'Dragged at Anne's Chariot Wheels': The Triangle of Author, Publisher, and Fictional Character." Gammel and Epperly, pp. 49-63.

Golding Page, Julie Rae. Kindred to the Spirit: A Christian Perspective on the Imagination as Portrayed in L.M. Montgomery's "Anne of Green Gables" Series. M.A. thesis, Regent College, 2000.

Golfman, Noreen. "Bleak Island." Review of The Blythes Are Quoted, by L.M. Montgomery, edited by Benjamin Lefebvre. Literary Review of Canada, Nov. 2009, p. 25.

Hammill, Faye. "'Something Wild and Sweet and Unutterable.'" Review of The Complete Journals of L.M. Montgomery: The PEI Years, 1901-1911, edited by Mary Henley Rubio and Elizabeth Waterston. Times Literary Supplement, 18 Oct. 2013, p. 21.

“harmony, n." OED Online, Oxford UP, June 2020, www.oed.com/view/Entry/84303. Accessed 31 Aug. 2020.

Hart, David Bentley. The Doors of the Sea: Where Was God in the Tsunami? Eerdmans, 2005.

Hick, John. Evil and the God of Love. Palgrave Macmillan, 2010.

Hilder, Monika B. "Imagining the Ultimate Kindred Spirit: The Feminist Theological Vision in L.M. Montgomery." Feminist Theology with a Canadian Accent: Canadian Perspectives on Contextual Feminist Theology, edited by Mary Ann Beavis, with Elaine Guillemin and Barbara Pell, Novalis Publishing, 2008, pp. 307-30. 
-. “'That Unholy Tendency to Laughter': L.M. Montgomery's Iconoclastic Affirmation of Faith in Anne of Green Gables." Canadian Children's Literature/Littérature canadienne pour la jeunesse, vol. 113-14, 2004, pp. 34-55.

Huse, Nancy. "Journeys of the Mother in the World of Green Gables." Children's Literature Association Quarterly, 1986 Proceedings, 1986, pp. 60-3.

Kessler, Deirdre. "L.M. Montgomery and the Creation of Prince Edward Island." Gammel and Epperly, pp. 229-34.

Klempa, Mary-Margaret. Passionate Blood, Puritan Conscience: An Intertextual Study of the Private and Public Works of L.M. Montgomery. M.A. thesis, Concordia U, 1998.

Kushner, Harold S. When Bad Things Happen to Good People. Anchor Books, 2004.

Lewis, C.S. The Problem of Pain. Geoffrey Bles, 1940.

Milton, John. Paradise Lost and Paradise Regained. Edited by Christopher Ricks, Penguin, 1982.

Montgomery, L.M. The Alpine Path: The Story of My Career. Fitzhenry and Whiteside, 1974.

—. Among the Shadows: Tales from the Darker Side. Edited by Rea Wilmhurst, McClelland and Stewart, 1992.

—. Anne of Green Gables. 1908. Seal, 1996.

—. Anne's House of Dreams. 1917. Seal, 1996.

-. The Complete Journals of L.M. Montgomery: The PEI Years, 1889-1911. Edited by Mary Rubio and Elizabeth Waterston, Oxford UP, 2012-13. 2 vols.

-. L.M. Montgomery's Complete Journals: The Ontario Years, 1911-33. Edited by Jen Rubio, Rock's Mills P, 2016-19. 5 vols.

—. Magic for Marigold. 1925. McClelland and Stewart, 1929.

—. The Watchman and Other Poems. McClelland, Goodchild and Stewart, 1916.

Nelles, Simone. Pilgrimages in a Land of Penumbra: A Critical Reading of the Religious Theme and Its Complex Variations in Lucy Maud Montgomery's Approaches 
toward Faith. M.A. thesis, Johannes Gutenberg University of Mainz, 1998.

Plantinga, Alvin. God, Freedom, and Evil. Eerdmans, 1989.

-. "Supralapsarianism, or 'O Felix Culpa.'" Christian Faith and the Problem of Evil, edited by Peter van Inwagen, Eerdmans, 2004, pp. 1-25.

Rubio, Mary Henley. “L.M. Montgomery: Scottish-Presbyterian Agency in Canadian Culture." Gammel and Epperly, pp. 89-105.

-. Lucy Maud Montgomery: The Gift of Wings. Doubleday Canada, 2008.

Rubio, Mary, and Elizabeth Waterston. "Afterword." Anne's House of Dreams, by L.M. Montgomery, Signet, 1989, pp. 277-86.

-. Introduction. The Selected Journals of L.M. Montgomery, Volume II: 1910-1921, by L.M. Montgomery, Oxford UP, 1987.

Scott, Mark S.M. "C.S. Lewis and John Hick: An Interface on Theodicy." The Journal of Inklings Studies. vol. 4, 2014, pp. 19-31.

-. Pathways in Theodicy: An Introduction to the Problem of Evil. Augsburg Fortress, 2015.

Sorfleet, John. "From Pagan to Christian: The Symbolic Journey of Anne of Green Gables." Windows and Words: A Look at Canadian Children's Literature in English, edited by Aïda Hudson and Susan-Ann Cooper, U of Ottawa P, 2003, pp. 175-83.

Stamelman, Richard. Lost Beyond Telling: Representations of Death and Absence in Modern French Poetry. Cornell UP, 1990.

Steffler, Margaret. “'Being a Christian' and a Presbyterian in Leaskdale.” Bode and Clement, pp. 54-73.

Swinburne, Richard. The Existence of God. Clarendon, 2004.

Thomas, Gillian. "The Decline of Anne: Matron vs. Child." Canadian Children's Literature/Littérature canadienne pour la jeunesse, vol. 1, no. 3, 1975, pp. 37-41.

Thompson, William V. "The Shadow on the House of Dreams: Montgomery's Revisioning of Anne." Bode and Clement, pp. 113-30. 
Van Inwagen, Peter. The Problem of Evil. Oxford UP, 2008.

Vincent, Alana M. Memorialisation and Jewish Theology in the 20th and 21st

Centuries: Monument, Narrative, Liturgy. Ph.D. thesis, University of Glasgow, 2010.

Walton, Heather, editor. Literature and Theology: New Interdisciplinary Spaces.

Ashgate Publishing, 2011.

White, Gavin. "The Religious Thought of L.M. Montgomery." Harvesting Thistles: The Textual Garden of L.M. Montgomery: Essays on Her Novels and Journal, edited by Mary Henley Rubio, Canadian Children's P, 1994, pp. 84-8.

Woster, Emily S. Intertextuality and Life Writing: The Reading Autobiography of L.M. Montgomery. Ph.D. dissertation, Illinois State University, 2013.

Wright, N.T. Evil and the Justice of God. IVP, 2006.

Zimmerman, Susan. Writing to Heal the Soul: Transforming Grief and Loss Through Writing. Three Rivers P, 2002. 